restraint on the other. The essential flavour of each wilderness is captured with great sensitivity. Wild animals, birds, plants, trees-Anthony Smith observes them well: but as a man-watcher he is even better. Through his eyes we see what life is really like, its glories and its miseries, for people on the edge of man's range in the world.

Illustrated by forty beautiful colour photographs the book concludes with the author's thoughts about the interplay of man and wilderness. He believes that the truly vast unfriendly wildernesses will take care of themselves for a long time to come, but he is more concerned about the smaller ones which man, especially in the USA, is trying to preserve. He fears that such areas will get over-organised and degenerate into parks. Unfortunately he offers no real solutions to the problems that must arise if a wilderness is invaded on the free-for-all lines he seems to favour. He is also unenthusiastic about protecting some endangered species: 'A rare bird nests and the people are kept from it', he complains. But what does he want to happen? I am sure that if its nests had not been guarded devotedly for many years the red kite would now be extinct in Britain. So we would have lost another precious fragment of our disappearing wilderness.

WILLIAM CONDRY

\title{
The Great Yew Forest: the natural history of Kingley Vale, by Richard Williamson. Macmillan, £5.95.
}

The Kingley Vale National Nature Reserve, high on the South Downs above Chichester Harbour, has a very special place in the affections of British conservationists. It combines high scientific interest with exceptional landscape and amenity value. Established in 1952 as one of the early reserves of the recently formed Nature Conservancy, it is a fitting memorial to the Conservancy's first chairman, Sir Arthur Tansley, who in the words of his memorial stone, sited at one of his favourite viewpoints, 'during a long lifetime strove with success to widen the knowledge, to deepen the love and to safeguard the heritage of nature in the British Isles'.

The reserve's 574 acres include what has been claimed as the finest yew forest of its type in Europe, chalk grassland and a well-developed acid heath. It is obvious that this unique reserve is fortunate in having as warden the author of this book, an enquiring, articulate naturalist and dedicated conservationist. His purpose, he says, 'is to describe the intricate workings of just over half a square mile of British countryside', and in prose worthy of a son of Henry Williamson, he gives an account of his efforts since his appointment in 1963 to find out the area's history, its present flora and fauna, and how best to manage them all. Naturally a detailed study of the yew forest came first in his priorities, and his account of the seed-spreading capabilities of birds such as the winter flocks of fieldfares makes interesting reading. He estimates that nearly half a million berries are scattered every year. There follow equally interesting accounts of the mammals-roe and fallow deer, fox, badger, stoats and weasels, and feral cats; the effects of the last are often overlooked.

Next in importance is the chalk grassland, and the account of its management for the two special features, the orchids and butterflies, is a valuable contribution to conservation knowledge. The Butterfly Monitoring Scheme, introduced by the Institute of Terrestrial Ecology in 1976, has revealed that Kingley Vale, by reason of its range of habitats and food-plants, as well as its enviable climate, is perhaps the richest in butterflies of any of our national nature reserves.

No fewer than ten appendices give flora and fauna lists, measurements of yews, numbers of visitors and other information. There is a bibliography and the book is illustrated by plans, photographs and attractive pen and ink drawings, presumably by the author as they are not acknowledged. 